\title{
ANALISIS MODEL MATEMATIKA PENYEBARAN PENYAKIT KOLERA DENGAN MEMPERTIMBANGKAN MASA INKUBASI
}

\author{
A. R. Nuha ${ }^{1}$ dan Resmawan ${ }^{2}$ \\ 1,2Program Studi Matematika Jurusan Matematika \\ FMIPA Universitas Negeri Gorontalo \\ 1agusyarif@ung.ac.id, 2resmawan@ung.ac.id
}

\begin{abstract}
Cholera is a type of diarrheal disease caused by the presence of Vibrio cholerae in the patient's intestine. Bacteria $V$. cholerae has the ability to survive in water so that it will easily transmit disease to humans. This study discusses the dynamics of the spread of cholera caused by $V$. cholerae bacteria. The incubation period in the disease transmission system is a factor that considered in a compiled mathematical model. Besides giving the vaccine is considered a powerful way to reduce the rate of transmission. This study aims to modify the mathematical model of the spread of cholera, carry out the analysis of the stability of the modified model, and carry out numerical simulations. The modified model will be determined by its equilibrium and then stability analysis will be carried out at the equilibrium by considering the basic reproduction number $\left(\mathcal{R}_{0}\right)$. Modification of the model with consideration of the incubation period produces a mathematical model of the spread of cholera type SVEIR-B. The stability of a fixed point is influenced by $\mathcal{R}_{0}$. The condition value $\mathcal{R}_{0}<1$ resulting in a disease-free equilibrium that is asymptotically stable, whereas the condition $\mathcal{R}_{0}>1$ results in an endemic equilibrium being asymptotically stable. Numerical simulations show an increase in the rate of vaccine delivery can decrease the value while increasing the rate of vaccine shrinkage and the incubation rate of each can increase the value.
\end{abstract}

Keywords : : Cholera, Mathematical Model, Reproduction Number, Stability Analysis

\section{ABSTRAK}

Penyakit kolera termasuk kedalam jenis penyakit diare yang disebabkan oleh adanya bakteri Vibrio cholerae di dalam usus penderita. Bakteri $V$. cholerae memiliki kemampuan untuk bertahan hidup di dalam air sehingga akan mudah menularkan penyakit kepada manusia. Penelitian ini membahas dinamika penyebaran penyakit kolera yang diakibatkan oleh bakteri $V$. cholerae. Adanya masa inkubasi dalam sistem penularan penyakit ini menjadi faktor yang dipertimbangkan dalam menyusun model matematika. Selain itu pemberian vaksin dianggap sebagai cara yang ampuh untu menekan laju penularan. Penelitian ini bertujuan untuk melakukan modifikasi model matematika penyebaran penyakit kolera, melakukan analisis kestabilan model hasil modifikasi, dan melakukan simulasi numerik. Model hasil modifikasi akan ditentukan titik tetapnya dan selanjutnya dilakukan analisis kestabilan pada titik tetap dengan pertimbangan bilangan reproduksi dasar $\left(\mathcal{R}_{0}\right)$. Modifikasi model dengan pertimbangan masa inkubasi menghasilkan model matematika penyebaran penyakit kolera tipe SVEIR-B. Sifat kestabilan titik tetap 
dipengaruhi oleh nilai $\mathcal{R}_{0}$. Kondisi $\mathcal{R}_{0}<1$ mengakibatkan titik tetap tanpa penyakit bersifat stabil asimtotik lokal, sebaliknya kondisi $\mathcal{R}_{0}>1$ mengakibatkan titik tetap endemik bersifat stabil asimtotik lokal. Simulasi numerik menunjukkan peningkatan laju pemberian vaksin dapat menurunkan nilai $\mathcal{R}_{0}$, sedangkan peningkatan laju penyusutan vaksin dan laju inkubasi masing masing dapat meningkatkan nilai $\mathcal{R}_{0}$.

Kata kunci $\quad$ : Kolera, Model Matematika, Bilangan Reproduksi Dasar, Analisis Kestabilan

\section{PENDAHULUAN}

Kolera merupakan jenis penyakit menular yang proses penularannya ditularkan oleh bakteri Vibrio cholerae. Seseorang yang rentan dapat tertular penyakit kolera jika mengkonsumsi makanan atau minuman yang sudah terkontaminasi dengan bakteri Vibrio cholerae. Penyakit ini dikategorikan sebagai diare akut dikarenakan terjadinya infeksi usus pada penderita akibat racun yang dikeluarkan oleh bakteri tersebut. Seseorang yang sudah terinfeksi penyakit kolera akan mengalami diare dan diikuti muntah secara terus-menerus (Puspandari, Sariadji dan Wati, 2010). Hal tersebut mengakibatkan penderita akan banyak kehilangan cairan tubuh hingga masuk pada kondisi dehidrasi.

Kolera telah menjadi masalah kesehatan Global, terutama pada daerah yang kekurangan akses air bersih dan sanitasi buruk (Shaikh et al., 2019). Jika tidak ditangani dengan tepat, maka penyakit kolera dapat mengakibatkan kematian bagi penderita (Side, Sukarna dan Asfarina, 2018). Berdasarkan data dari WHO penyakit ini pertama kali menyebar pada tahun 1817 di wilayah Asia Tenggara dan kemudian berkembang menjadi epidemi global. Selain itu pada tahun 1961 penyakit kolera pertama kali muncul di Indonesia dan menyebar dengan cepat ke Negara-Negara lain di Asia, Eropa, dan Afrika. Tahun 1991 penyakit ini juga menyebar dengan cepat di Amerika Latin dan dilaporkan lebih dari 400.000 orang terinfeksi dan 4.000 orang meninggal. Oleh karena itu, pencegahan dan pengendalian penyebaran kolera harus menjadi prioritas utama di daerah beresiko tingi atau dimana wabah kolera akan muncul (WHO, 2017). Penggunaan vaksin merupakan suatu cara atau metode yang ampuh untuk mencegah dan mengendalikan penyebaran penyakit kolera (Pezzoli, 2019). Hal ini dibuktikan dengan penggunaan vaksin ditahun 2011 mampu memberikan efek yang sangat cepat untuk mengatasi penyebaran penyakit kolera (WHO, 2017). Namun perizinan dan keputusan penggunaan vaksin bergantung pada program pengembangan kesehatan dengan memperhatikan resiko serta manfaat vaksin pada populasi target (Vannice et al., 2018).

Penelitian terhadap penyebaran penyakit kolera merupakan salah satu cara untuk melakukan pencegahan dan pengendalian penyakit. Dalam bidang matematika, penelitian dapat dilakukan dengan membuat atau merumuskan model matematika yang dapat memberikan gambaran serta efek perubahan populasi diakibatkan oleh penyakit kolera. Beberapa model matematika mengenai penyebaran penyakit kolera diantaranya, model epidemik tipe SIR yang dikembangkan oleh Codeco (Codeco, 2001), dimana S (Susceptible), I (Infected), dan R (Recovered) berturut-turut menyatakan populasi rentan, terinfeksi dan sembuh. Kemudian Wang dan Modnak (Wang dan Modnak, 2011) merumuskan model epidemik tipe SIR-B, dimana B (Bacteri) menyatakan konsentrasi bakteri Vibrio cholerae yang terdapat di air. Selanjutnya pada tahun 2019 Tian et al (Tian, Xu dan Lin, 2019) 
mengembangkan model matematika tipe SVIR-B dengan $\mathrm{V}$ (Vaccinated) yang menyatakan pengaruh vaksin untuk menekan penyebaran penyakit kolera.

Proses transmisi penyakit kolera memiliki masa inkubasi yaitu waktu yang diperlukan oleh bakteri untuk berlipatganda hingga dapat menimbulkan gejala pada inangnya. Dimana $95 \%$ dari orang yang terkontaminasi dengan bakteri Vibrio cholerae memiliki masa inkubasi selama 4,4 hari serta $5 \%$ diantaranya dapat berlangsung selama 1,4 hari. Oleh karena itu, dalam penelitian ini dilakukan modifikasi model Tian et al (Tian, Xu dan Lin, 2019) dengan mempertimbangkan masa inkubasi. Tujuan dari penelitian ini adalah melakukan modifikasi model matematika penyebaran penyakit kolera, melakukan analisis kestabilan di sekitar titik tetap model hasil modifikasi, dan melakukan simulasi numerik pada model hasil modifikasi untuk melihat dinamika penyebaran penyakit kolera.

\section{METODE PENELITIAN}

Bentuk penelitian ini adalah studi literatur dengan tahapan sebagai berikut: (1) menentukan masalah, (2) merumuskan masalah, (3) kajian teori, (4) analisis untuk penyelesaian masalah, dan (5) penarikan kesimpulan. Penentuan dan perumusan masalah diperlukan agar bahan kajian difokuskan pada masalah yang akan dikaji, sehingga penyusunan langkah-langkah penyelesaian dapat dilakukan dengan mudah. Kajian teori dilakukan dengan mengumpulkan sumber pustaka agar diperoleh gambaran proses penyebaran penyakit kolera, model matematika, sistem persamaan diferensial, titik kesetimbangan, nilai eigen dan vektor eigen, bilangan reproduksi dasar $\left(\mathcal{R}_{0}\right)$, syarat kestabilan titik tetap, indeks sensitivitas dan simulasi numerik.

Untuk penyelesian masalah dilakukan dengan beberapa tahapan sebagai berikut; (1) merumuskan model matematika penyebaran penyakit kolera, (2) menentukan titik kesetimbangan model, (3) menentukan bilangan reproduksi dasar $\left(\mathcal{R}_{0}\right)$, (4) menentukan syarat kestabilan disekitar titik tetap, (5) melakukan simulasi numerik disertai dengan menghitung nilai indeks sensitivitas, (6) menginterpretasikan solusi yang diperoleh.

\section{HASIL DAN PEMBAHASAN}

\subsection{Model Matematika}

Model dasar atau acuan pada penelitian ini adalah model matematika penyebaran penyakit kolera yang dirumuskan oleh Tian, Xu dan Lin, (2019). Desngan melakukan modifikasi pada model dasar dihasilkan model matematika penyebaran penyakit kolera tipe SVEIR-B. Model tersebut terdiri atas populasi manusia dan populasi bakteri. Populasi manusia terbagi atas lima kelas subpopulasi, yaitu populasi manusia rentan atau susceptible $(S)$, populasi manusia yang diberi vaksin atau vaccinated $(V)$, populasi manusia terpapar atau exposed $(E)$, populasi manusia terinfeksi atau infected $(I)$, dan populasi manusia sembuh atau recovered $(R)$. Sedangkan populasi bakteri hanya terdiri atas satu kelas yaitu populasi bacteria $(B)$. 
Laju kelahiran manusia adalah sebesar $A$, dimana setiap individu (manusia) yang baru lahir akan masuk kedalam subpopulasi rentan. Sebagian dari populasi rentan mendapatkan vaksin sebesar $\phi$, yang kemudian akan dimasukan kedalam populasi tervaksin. Vaksin tersebut akan meningkatkan daya tahan tubuh manusia agar tidak mudah terpapar virus. Namun tidak semua vaksin dapat berfungsi secara efektif. Laju penurunan efektivitas vaksin adalah sebesar $\sigma$, dengan $0 \leq \sigma \leq 1$. Jika $\sigma=1$, maka vaksin tersebut tidak efektif dalam melakukan pencegahan infeksi. Selain itu seiring dengan berjalannya waktu vaksin yang berada pada tubuh manusia akan terus berkurang (menyusut) dengan laju sebesar $\eta$.

Individu rentan yang tidak diberi vaksin akan mudah tekena penyakit dan masuk kedalam populasi terpapar dengan laju sebesar $\beta$. Hal serupa juga akan dialami oleh individu tervaksin dengan tingkat efektivitas vaksin yang rendah. Penularan penyakit tersebut disebabkan oleh adanya kontak antara manusia dengan bakteri Vibrio cholerae. Individu terpapar akan memasuki masa inkubasi dengan laju sebesar $\psi$. Jika masa inkubasi telah berakhir maka individu terpapar akan masuk kedalam kelas individu terinfeksi. Keberadaan individu terinfeksi ini menambah jumlah populasi bakteri di lingkungan sebesar $\xi$. Sebagian dari individu terinfeksi akan mengalami penyembuhan dan masuk kedalam subpopulasi sembuh dengan laju sebesar $\gamma$. Setiap individu memiliki kemungkinan untuk mengalami kematian, dengan laju kematian alami untuk manusia sebesar $\mu$, kematian manusia karena penyakit sebesar $d$, dan kematian bakteri sebesar $\delta$.

Dinamika penyebaran penyakit kolera pada model ini disajikan dalam bentuk diagram kompartemen. Tujuan dari diagram kompartemen tersebut adalah untuk memudahkan penyusunan sistematika proses penyebaran penyakit kedalam bentuk sistem persamaan diferensial. Selanjutnya diagram kompartemen dapat dilihat pada Gambar 1.

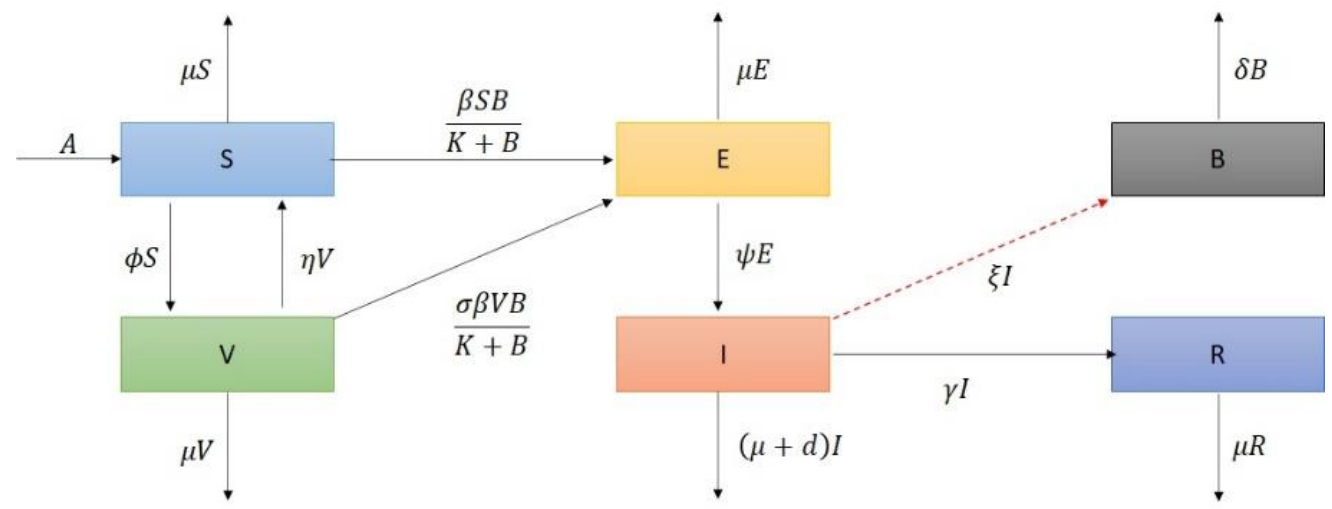

Gambar 2 : Skema Model Penyebaran Penyakit Kolera. 
Berdasarkan diagram kompartemen pada Gambar 1, dirumuskan sistem persamaan diferensial sebagai berikut:

$$
\begin{aligned}
& \frac{d S}{d t}=A+\eta V-\phi S-\left(\frac{\beta S B}{K+B}\right)-\mu S \\
& \frac{d V}{d t}=\phi S-\eta V-\mu V-\frac{\sigma \beta V B}{K+B} \\
& \frac{d E}{d t}=\left(\frac{\beta S B}{K+B}\right)+\frac{\sigma \beta V B}{K+B}-\psi E-\mu E \\
& \frac{d I}{d t}=\psi E-(\mu+d+\gamma) I \\
& \frac{d B}{d t}=\xi I-\delta B \\
& \frac{d R}{d t}=\gamma I-\mu R
\end{aligned}
$$

Untuk selanjutnya akan ditentukan titik tetap dari sistem (1) dan dianalisis sifat kestabilan dari titik tetap tersebut.

\subsection{Analisis Model}

Sistem persamaan (1) memiliki dua titik tetap, yaitu titik tetap bebas penyakit $T_{0}(S, V, E, I, B, R)=\left(\frac{A(\eta+\mu)}{\mu(\eta+\mu+\phi)}, \frac{A \phi}{\mu(\eta+\mu+\phi)}, 0,0,0,0\right)$ dan titik tetap endemik $T^{*}(S, V, E, I, B, R)=$ $\left(S^{*}, V^{*}, E^{*}, I^{*}, B^{*}, R^{*}\right)$, dimana:

$$
\begin{array}{ll}
S^{*}=\frac{\left(B^{*}+K\right)\left(A+V^{*} \eta\right)}{K(\mu+\phi)+B^{*}(\beta+\mu+\phi)} & V^{*}=\frac{\left(B^{*}+K\right) \phi S^{*}}{\left(B^{*}+K\right)(\eta+\mu)+B^{*} \beta \sigma} \\
E^{*}=\frac{B^{*} \beta\left(S^{*}+V^{*} \sigma\right)}{\left(B^{*}+K\right)(\mu+\psi)} & I^{*}=\frac{\psi E^{*}}{d+\gamma+\mu} \\
B^{*}=\frac{\xi I^{*}}{\delta} & R^{*}=\frac{\gamma I^{*}}{\mu}
\end{array}
$$

Bilangan reproduksi dasar dapat digunakan untuk melihat ambang batas epidemi (Allen dan Lahodny Jr, 2012). Penentuan bilangan reproduksi dasar dilakukan dengan menggunakan pendekatan the next generation matrix (Driessche dan Watmough, 2002). Berdasarkan pendekatan tersebut diperoleh matriks $F$ dan $V$ yang dievaluasi pada titik tetap $T_{0}$, yaitu:

$$
\begin{aligned}
& F=\left(\begin{array}{ccc}
0 & 0 & \frac{A \beta(\eta+\mu)}{K \mu(\eta+\mu+\phi)}+\frac{A \beta \sigma \phi}{K \mu(\eta+\mu+\phi)} \\
0 & 0 & 0 \\
0 & 0 & 0
\end{array}\right), \\
& V=\left(\begin{array}{ccc}
\mu+\psi & 0 & 0 \\
-\psi & d+\gamma+\mu & 0 \\
0 & -\xi & \delta
\end{array}\right)
\end{aligned}
$$

Bilangan reproduksi dasar adalah nilai eigen positif terbesar dari matriks $F V^{-1}$, yaitu:

$$
\mathcal{R}_{0}=\rho\left(F V^{-1}\right)=\frac{A \beta \xi(\eta+\mu+\sigma \phi) \psi}{K \delta \mu(d+\gamma+\mu)(\eta+\mu+\phi)(\mu+\psi)}
$$

Teorema 1. Jika $\mathcal{R}_{0}<1$, maka titik tetap tanpa penyakit $T_{0}$ pada sistem (1) bersifat stabil asimtotik lokal. 
Bukti. Matriks Jacobi untuk titik tetap tanpa penyakit $T_{0}$ pada sistem (1) adalah sebagai berikut:

$$
J_{T_{0}}=\left(\begin{array}{cccccc}
-\mu-\phi & \eta & 0 & 0 & -\frac{A \beta(\eta+\mu)}{K \mu(\eta+\mu+\phi)} & 0 \\
\phi & -\eta-\mu & 0 & 0 & -\frac{A \beta \sigma \phi}{K \mu(\eta+\mu+\phi)} & 0 \\
0 & 0 & -\mu-\psi & 0 & \frac{A \beta(\eta+\mu)}{K \mu(\eta+\mu+\phi)}+\frac{A \beta \sigma \phi}{K \mu(\eta+\mu+\phi)} & 0 \\
0 & 0 & \psi & -d-\gamma-\mu & 0 & 0 \\
0 & 0 & 0 & \xi & -\delta & -\mu
\end{array}\right)
$$

dengan persamaan karakteristik berbentuk :

$$
\operatorname{det}\left(J_{T_{0}}-\lambda I\right)=0
$$

atau

$$
\begin{aligned}
& \left(\lambda-a_{66}\right)\left(\lambda^{2}-\left(a_{11}+a_{22}\right) \lambda-a_{12} a_{21}+a_{11} a_{22}\right) \\
& \left(\lambda^{3}-\left(a_{33}+a_{44}+a_{55}\right) \lambda^{2}+\left(a_{33} a_{44}+a_{33} a_{55}+a_{44} a_{55}\right) \lambda-a_{35} a_{43} a_{54}-a_{33} a_{44} a_{55}\right)=0
\end{aligned}
$$

dimana:

$$
\begin{aligned}
& a_{11}=-\mu-\phi, \\
& a_{12}=\eta, \\
& a_{21}=\phi, \\
& a_{22}=-\eta-\mu, \\
& a_{33}=-\mu-\psi, \\
& a_{35}=\frac{A \beta(\eta+\mu)}{K \mu(\eta+\mu+\phi)}+\frac{A \beta \sigma \phi}{K \mu(\eta+\mu+\phi)^{\prime}} \\
& a_{43}=\psi, \\
& a_{44}=-d-\gamma-\mu, \\
& a_{54}=\xi, \\
& a_{55}=-\delta, \\
& a_{66}=-\mu .
\end{aligned}
$$

Berdasarkan persamaan (4) diperoleh

$$
\begin{aligned}
& \lambda_{1}=-\mu, \\
& \lambda^{2}-\left(a_{11}+a_{22}\right) \lambda+a_{11} a_{22}-a_{12} a_{21}=0,
\end{aligned}
$$

dan

$\lambda^{3}-\left(a_{33}+a_{44}+a_{55}\right) \lambda^{2}+\left(a_{33} a_{44}+a_{33} a_{55}+a_{44} a_{55}\right) \lambda-a_{35} a_{43} a_{54}-a_{33} a_{44} a_{55}=0$.

Karena semua parameter bernilai positif, maka $\lambda_{1}<0$.

Dua nilai eigen lainnya diperoleh dengan menganalisis sifat akar persamaan kuadrat pada persamaan (5), yaitu

$$
\begin{aligned}
& \lambda_{2}+\lambda_{3}=a_{11}+a_{22}, \\
& \lambda_{2} \lambda_{3}=a_{11} a_{22}-a_{12} a_{21} .
\end{aligned}
$$

Karena $a_{11}$ dan $a_{22}$ bernilai positif maka $\lambda_{2}+\lambda_{3}<0$. Hal ini menandakan salah satu dari nilai eigen tersebut bernilai negatif, anggap $\lambda_{2}<0$. Dari persamaan (8) diperoleh

$$
\lambda_{2} \lambda_{3}=\mu(\eta+\mu)+\phi \mu
$$


akibatnya $\lambda_{2} \lambda_{3}>0$. Karena $\lambda_{2}<0$, maka haruslah $\lambda_{3}<0$.

Selanjutnya tiga nilai eigen lainnya diperoleh dengan menyelesaikan persamaan (6).

Berdasarkan sifat akar persamaan kubik diperoleh

$$
\begin{aligned}
& \lambda_{4}+\lambda_{5}+\lambda_{6}=a_{33}+a_{44}+a_{55} \\
& \lambda_{4} \lambda_{5}+\lambda_{4} \lambda_{6}+\lambda_{5} \lambda_{6}=a_{33} a_{44}+a_{33} a_{55}+a_{44} a_{55} \\
& \lambda_{4} \lambda_{5} \lambda_{6}=a_{35} a_{43} a_{54}+a_{33} a_{44} a_{55}
\end{aligned}
$$

Karena semua parameter bernilai positif maka

$$
\lambda_{4}+\lambda_{5}+\lambda_{6}<0
$$

Akibatnya, salah satu dari ketiga nilai eigen bernilai negatif, anggap $\lambda_{4}<0$.

Dari persamaan (10) diperoleh

$$
\lambda_{4} \lambda_{5}+\lambda_{4} \lambda_{6}+\lambda_{5} \lambda_{6}=(\mu+\psi)(\delta)+(\mu+\psi)(d+\gamma+\mu)+(d+\gamma+\mu) \delta .
$$

Hal ini menunjukkan bahwa

$$
\lambda_{4}\left(\lambda_{5}+\lambda_{6}\right)+\lambda_{5} \lambda_{6}>0
$$

Selanjutnya, berdasarkan persamaan (11), diperoleh

$$
\lambda_{4} \lambda_{5} \lambda_{6}=\frac{A \beta \psi \xi(\eta+\mu+\sigma \phi)}{K \mu(\eta+\mu+\phi)}-(\mu+\psi)(d+\gamma+\mu) \delta
$$

Karena $\mathcal{R}_{0}<1$, maka

$$
\begin{gathered}
\frac{A \beta \xi(\eta+\mu+\sigma \phi) \psi}{K \delta \mu(d+\gamma+\mu)(\eta+\mu+\phi)(\mu+\psi)}<1 \\
\frac{A \beta \psi \xi(\eta+\mu+\sigma \phi)}{K \mu(\eta+\mu+\phi)}<(\mu+\psi)(d+\gamma+\mu) \delta
\end{gathered}
$$

akibatnya

$$
\lambda_{4} \lambda_{5} \lambda_{6}<0
$$

Karena $\lambda_{4}<0$ dan berdasarkan kondisi (14) maka

$$
\lambda_{5} \lambda_{6}>0
$$

Kondisi (13) dan (15) hanya dapat dipenuhi jika

$$
\lambda_{5}+\lambda_{6}<0
$$

Akibat dari (15) dan (16) adalah $\lambda_{5}<0$ dan $\lambda_{6}<0$. Sehingga diperoleh semua nilai eigen negatif. Dengan demikian terbukti jika $\mathcal{R}_{0}<1$, maka titik tetap $T_{0}$ bersifat stabil asimtotik lokal.

Teorema 2. Titik tetap tanpa penyakit $T_{0}$ akan selalu ada, serta titik tetap endemik $T^{*}$ unik dan positif jika dan hanya jika $\mathcal{R}_{0}>1$.

Bukti. Perhatikan kembali titik tetap endemik $T^{*}$ pada sistem (1)

$$
\begin{aligned}
& S^{*}=\frac{\left(B^{*}+K\right)\left(A+V^{*} \eta\right)}{K(\mu+\phi)+B^{*}(\beta+\mu+\phi)} \\
& V^{*}=\frac{\left(B^{*}+K\right) S^{*} \phi}{\left(B^{*}+K\right)(\eta+\mu)+B^{*} \beta \sigma} \\
& E^{*}=\frac{B^{*} \beta\left(S^{*}+V^{*} \sigma\right)}{\left(B^{*}+K\right)(\mu+\psi)} \\
& I^{*}=\frac{E^{*} \psi}{d+\gamma+\mu} \\
& B^{*}=\frac{I^{*} \xi}{\delta} \\
& R^{*}=\frac{I^{*} \gamma}{\mu}
\end{aligned}
$$


Dengan melakukan subtitusi persamaan (17), (18), (20), dan (21) kedalam persamaan (19) diperoleh

$E^{*}\left(P_{1} E^{* 2}+P_{2} E^{*}+P_{3}\right)=0$

Dimana

$$
\begin{gathered}
P_{1}=-\frac{\xi^{2}((\beta+\mu)(\eta+\mu+\beta \sigma)+(\mu+\beta \sigma) \phi)(\mu+\psi) \psi^{2}}{K \delta \mu(d+\gamma+\mu)(\eta+\mu+\phi)(\mu+\psi)}, \\
P_{2}=\xi \psi\left(\mathcal{R}_{0}-1+\frac{A \beta^{2} \xi \sigma \psi}{k \delta \mu(d+\gamma+\mu)(\eta+\mu+\phi)(\mu+\psi)}-\frac{\beta(\eta+\mu+\mu \sigma+\sigma \phi)+\mu(\eta+\mu+\phi)}{\mu(\eta+\mu+\phi)}\right) \\
P_{3}=k \delta(d+\gamma+\mu)\left(\mathcal{R}_{0}-1\right) .
\end{gathered}
$$

Persamaan (23) memiliki tiga akar persamaan, salah satunya adalah $E^{*}=0$. Berdasarkan persamaan (20), (21), dan (22) nilai $E^{*}=0$ akan mengakibatkan $I^{*}=0, B^{*}=0$, dan $R^{*}=0$. Berdasarkan persamaan (17) dan (18) diperoleh $S^{*}=\frac{A(\eta+\mu)}{\mu(\eta+\mu+\phi)}$ dan $V^{*}=\frac{A \phi}{\mu(\eta+\mu+\phi)}$. Nilai yang diperoleh ini merupakan titik tetap tanpa penyakit $T_{0}$ pada sistem (1). Jadi terbukti bahwa titik tetap tanpa penyakit $T_{0}$ akan selalu ada.

Dua akar persamaan lainnya diperoleh dengan menyelesaikan persamaan

$P_{1} E^{* 2}+P_{2} E^{*}+P_{3}=0$

Menggunakan sifat akar persamaan kuadrat pada persamaan (24) diperoleh

$E_{1}^{*}+E_{2}^{*}=-\frac{P_{2}}{P_{1}}$

$E_{1}^{*} E_{2}^{*}=\frac{P_{3}}{P_{1}}$

Misalkan $\mathcal{R}_{0}>1$ akan dibuktikan $T^{*}$ unik dan positif. Nilai $\mathcal{R}_{0}>1$ mengakibatkan $P_{3}>0$. Karena $\quad P_{1}<0$ diperoleh

$E_{1}^{*} E_{2}^{*}<0$

Kondisi (27) hanya akan terpenuhi jika $E_{1}^{*}$ dan $E_{2}^{*}$ memiliki tanda berbeda. Dengan demikian hanya terdapat satu akar positif $E^{*}$. Jadi dapat disimpulkan bahwa $S^{*}, V^{*}, I^{*}, B^{*}$ dan $R^{*}$ ada serta memiliki nilai unik dan positif berdasarkan persamaan (17), (18), (20), (21), dan (22).

Misalkan $T^{*}$ unik dan positif, akan dibuktikan $\mathcal{R}_{0}>1$.

Andaikan $\mathcal{R}_{0}<1$, maka diperoleh

$A \beta \xi(\eta+\mu+\sigma \phi) \psi<K \delta \mu(d+\gamma+\mu)(\eta+\mu+\phi)(\mu+\psi)$

Dari pertidaksamaan (28) diperoleh

$A \beta^{2} \xi \psi(\eta+\mu+\sigma \phi)<\beta K \delta \mu(d+\gamma+\mu)(\eta+\mu+\phi)(\mu+\psi)$

Karena $0 \leq \sigma \leq 1$ dan berdasarkan pertidaksamaan (29) diperoleh

$A \beta^{2} \xi \psi \sigma(\eta+\mu+\phi)<\beta K \delta \mu(d+\gamma+\mu)(\eta+\mu+\phi)(\mu+\psi)$

Dari pertidaksamaan (30) diperoleh

$A \beta^{2} \xi \psi \sigma \mu(\eta+\mu+\phi)<\beta K \delta \mu(d+\gamma+\mu)(\eta+\mu+\phi)(\mu+\psi)\left((\eta+\mu+\mu \sigma+\sigma \phi)+\frac{\mu}{\beta}(\eta+\mu+\phi)\right)$

Dari pertidaksamaan (31) diperoleh 
$A \beta^{2} \xi \psi \sigma \mu(\eta+\mu+\phi)<K \delta \mu(d+\gamma+\mu)(\eta+\mu+\phi)(\mu+\psi)(\beta(\eta+\mu+\mu \sigma+\sigma \phi)+\mu(\eta+\mu+\phi)$

Dari pertidaksamaan (32) diperoleh

$$
\frac{A \beta^{2} \xi \sigma \psi}{K \delta \mu(d+\gamma+\mu)(\eta+\mu+\phi)(\mu+\psi)}<\frac{\beta(\eta+\mu+\mu \sigma+\sigma \phi)+\mu(\eta+\mu+\phi)}{\mu(\eta+\mu+\phi)}
$$

Akibatnya diperoleh $P_{2}<0$. Karena $\mathcal{R}_{0}<1$ maka $P_{3}<0$. Berdasarkan kondisi (25) dan (26) diperoleh $\quad E_{1}^{*}+E_{2}^{*}<0$ dan $E_{1}^{*} E_{2}^{*}>0$ yang hanya dapat dipenuhi jika $E_{1}^{*}<0$ dan $E_{2}^{*}<0$. Dengan demikian tidak terdapat titik tetap endemik $T^{*}$ positif. Jadi agar titik tetap endemik $T^{*}$ unik dan positif maka haruslah $\mathcal{R}_{0}>1$.

Andaikan $\mathcal{R}_{0}=1$, maka diperoleh

$A \beta \xi \psi(\eta+\mu+\sigma \phi)=K \delta \mu(d+\gamma+\mu)(\eta+\mu+\phi)(\mu+\psi)$

Dari persamaan (34) diperoleh

$A \beta^{2} \xi \psi \mu(\eta+\mu+\sigma \phi)=K \delta \mu \beta(d+\gamma+\mu)(\eta+\mu+\phi)(\mu+\psi) \mu$

Dari persamaan (35) diperoleh

$A \beta^{2} \xi \psi \mu(\eta+\mu+\sigma \phi)<K \delta \mu \beta(d+\gamma+\mu)(\eta+\mu+\phi)(\mu+\psi)\left((\eta+\mu+\mu \sigma+\sigma \phi)+\frac{\mu}{\beta}(\eta+\mu+\phi)\right)$

Karena $0 \leq \sigma \leq 1$ dan berdasarkan pertidaksamaan (36) diperoleh

$A \beta^{2} \xi \psi \sigma \mu(\eta+\mu+\phi)<K \delta \mu(d+\gamma+\mu)(\eta+\mu+\phi)(\mu+\psi)(\beta(\eta+\mu+\mu \sigma+\sigma \phi)+\mu(\eta+\mu+\phi)$

Dari pertidaksamaan (37) diperoleh

$\frac{A \beta^{2} \xi \sigma \psi}{K \delta \mu(d+\gamma+\mu)(\eta+\mu+\phi)(\mu+\psi)}<\frac{\beta(\eta+\mu+\mu \sigma+\sigma \phi)+\mu(\eta+\mu+\phi)}{\mu(\eta+\mu+\phi)}$

Sehingga diperoleh $P_{2}<0$. Karena $\mathcal{R}_{0}=1$ maka $P_{3}=0$. Berdasarkan kondisi (25) dan (26) diperoleh $E_{1}^{*}+E_{2}^{*}<0$ dan $E_{1}^{*} E_{2}^{*}=0$. Hal ini hanya akan dipenuhi jika salah satu akar bernilai nol dan akar lainnya bernilai negatif. Dengan demikian tidak terdapat titik tetap endemik $T^{*}$ unik dan positif. Jadi, agar titik tetap endemik $T^{*}$ unik dan positif, maka haruslah $\mathcal{R}_{0}>1$.

Teorema 3. Jika $\mathcal{R}_{0}>1$, maka titik tetap endemik $T^{*}$ pada sistem (1) bersifat stabil asimtotik lokal.

Bukti. Misalkan $\varphi=\beta$ adalah parameter bifurkasi. Misalkan juga $x_{1}=S, x_{2}=V, x_{3}=E, x_{4}=I$, $x_{5}=B$, dan $x_{6}=R$. Sehingga sistem (1) berubah menjadi

$f_{1}\left(x_{1}, x_{2}, x_{3}, x_{4}, x_{5}, x_{6}\right)=A+\eta x_{2}-\phi x_{1}-\left(\frac{\beta x_{1} x_{5}}{K+x_{5}}\right)-\mu x_{1}$,

$f_{2}\left(x_{1}, x_{2}, x_{3}, x_{4}, x_{5}, x_{6}\right)=\phi x_{1}-\eta x_{2}-\mu x_{2}-\frac{\sigma \beta x_{2} x_{5}}{K+x_{5}}$

$f_{3}\left(x_{1}, x_{2}, x_{3}, x_{4}, x_{5}, x_{6}\right)=\left(\frac{\beta x_{1} x_{5}}{K+x_{5}}\right)+\frac{\sigma \beta x_{2} x_{5}}{K+x_{5}}-\psi x_{3}-\mu x_{3}$,

$f_{4}\left(x_{1}, x_{2}, x_{3}, x_{4}, x_{5}, x_{6}\right)=\psi x_{3}-(\mu+d+\gamma) x_{4}$

$f_{5}\left(x_{1}, x_{2}, x_{3}, x_{4}, x_{5}, x_{6}\right)=\xi x_{4}-\delta x_{5}$

$f_{6}\left(x_{1}, x_{2}, x_{3}, x_{4}, x_{5}, x_{6}\right)=\gamma x_{4}-\mu x_{6}$.

Kondisi $\mathcal{R}_{0}=1$ bersesuain dengan

$\varphi=\varphi^{*}=\frac{K \delta \mu(d+\gamma+\mu)(\eta+\mu+\phi)(\mu+\psi)}{A \xi(\eta+\mu+\sigma \phi) \psi}$

serta titik tetap tanpa penyakit $\mathcal{R}_{0}=1$ mempunyai lima nilai eigen negatif dan satu nilai eigen nol. Nilai eigen nol tersebut memiliki vektor eigen kanan $\left(u_{1}, u_{2}, u_{3}, u_{4}, u_{5}, u_{6}\right)$ dan vektor eigen kiri $\left(v_{1}, v_{2}, v_{3}, v_{4}, v_{5}, v_{6}\right)$ sebagai berikut. 
Misal $u_{5}>0$ bebas, maka

$u_{1}=-\frac{A \beta\left((\eta+\mu)^{2}+\eta \sigma \phi\right)}{K \mu^{2}(\eta+\mu+\phi)^{2}} u_{5}<0, u_{2}=-\frac{A \beta \phi(\eta+\mu+\mu \sigma+\sigma \phi)}{k \mu^{2}(\eta+\mu+\phi)^{2}} u_{5}<0, u_{3}=\frac{A \beta(\eta+\mu+\sigma \phi)}{K \mu(\eta+\mu+\phi)(\mu+\psi)} u_{5}>0$,

$u_{4}=\frac{\delta}{\xi} u_{5}>0, u_{6}=\frac{\gamma \delta}{\mu \xi} u_{5}>0, v_{1}=v_{2}=v_{6}=0$.

Misal $v_{3}>0$ bebas, maka

$v_{4}=\frac{(\mu+\psi)}{\psi} v_{3}>0, \quad v_{5}=-\frac{A \beta(\eta+\mu+\sigma \phi)}{K \mu(\eta+\mu+\phi)} v_{3}<0$.

Menggunakan Teorema Castillo-chavez dan Song (2004) didefinisikan

$a=\sum_{k, i, j=1}^{6} v_{k} u_{i} u_{j} \frac{\partial^{2} f_{k}}{\partial x_{i} \partial x_{j}}\left(T^{0}, \varphi^{*}\right), \quad b=\sum_{k, i, j=1}^{6} v_{k} u_{i} \frac{\partial^{2} f_{k}}{\partial x_{i} \partial \varphi}\left(T^{0}, \varphi^{*}\right)$

Berdasarkan sistem (39) diperoleh

$\frac{\partial^{2} f_{3}}{\partial x_{1} \partial x_{5}}\left(T^{0}, \varphi^{*}\right)=\frac{\varphi^{*}}{K}, \quad \frac{\partial^{2} f_{3}}{\partial x_{2} \partial x_{5}}\left(T^{0}, \varphi^{*}\right)=\frac{\varphi^{*} \sigma}{K}, \frac{\partial^{2} f_{3}}{\partial x_{5} \partial \varphi}\left(T^{0}, \varphi^{*}\right)=\frac{A(\eta+\mu)}{K \mu(\eta+\mu+\phi)}+\frac{A \sigma \phi}{K \mu(\eta+\mu+\phi)}$.

Berdasarkan persamaan (40) diperoleh

$a=-\frac{A u_{5} \varphi^{* 2}\left((\eta+\mu)^{2}+\sigma(2 \eta+\mu+\mu \sigma) \phi+\sigma^{2} \phi^{2}\right)}{K^{2} \mu^{2}(\eta+\mu+\phi)^{2}} u_{5} v_{3}<0$,

$b=\frac{A(\eta+\mu+\sigma \phi)}{K \mu(\eta+\mu+\phi)} u_{5} v_{3}>0$.

Nilai $a$ dan $b$ diatas memenuhi kasus 4 pada Teorema Castillo-Chaves dan Song (Castillochavez dan Song, 2004). Hal ini menunjukkan ketika $\varphi$ berubah dari $\varphi\left\langle\varphi^{*}\right.$ menjadi $\varphi>\varphi^{*}$ akan mengakibatkan perubahan pada titik tetap $T_{0}$ dari stabil menjadi tidak stabil. Selain itu, terjadi perubahan pada titik tetap endemik $T^{*}$ dari negatif menjadi positif dan stabil asimtotik lokal.

\subsection{Simulasi Numerik}

Simulai numerik dilakukan untuk menunjukkan kembali kondisi atau kestabilan titik tetap sistem (1) secara numerik. Selain itu, simulasi numerik bertujuan untuk melihat dinamika populasi pada model berdasarkan nilai-nilai parameter yang diberikan. Nilai-nilai parameter tersebut juga akan divariasikan sesuai dengan kemungkinan yang akan terjadi didunia nyata. Seluruh nilai parameter yang akan digunakan dapat dilihat pada Tabel 1.

Tabel 1 : Nilai Parameter Yang Digunakan

\begin{tabular}{|c|c|c|c|c|}
\hline Parameter & Simbol & Kasus 1 & Kasus 2 & Sumber \\
\hline Laju kelahiran alami & $A$ & $0,1 /$ hari & $0,1 /$ hari & $\begin{array}{l}\text { (Tian, et al., } \\
\text { 2019) }\end{array}$ \\
\hline Laju vaksinasi & $\phi$ & $0,01 /$ hari & $0,01 /$ hari & $\begin{array}{l}\text { (Tian, et al., } \\
\text { 2019) }\end{array}$ \\
\hline $\begin{array}{l}\text { Laju transmisi bakteri dari } \\
\text { lingkungan ke manusia }\end{array}$ & $\beta$ & $0,2143 /$ hari & $0,2143 /$ hari & $\begin{array}{l}\text { (Tian, et al., } \\
\text { 2019) }\end{array}$ \\
\hline $\begin{array}{l}\text { Konsentrasi jenuh bakteri } \\
\text { dalam air }\end{array}$ & $K$ & $10^{6} \mathrm{sel} / \mathrm{ml}$ & $10^{6} \mathrm{sel} / \mathrm{ml}$ & $\begin{array}{l}\text { (Tian, et al., } \\
\text { 2019) }\end{array}$ \\
\hline
\end{tabular}




\begin{tabular}{|c|c|c|c|c|c|c|}
\hline Laju penyusutan vaksin & $\eta$ & $0,005 /$ hari & $0,005 /$ hari & $\begin{array}{l}\text { (Tian, } \\
\text { 2019) }\end{array}$ & et & al., \\
\hline Laju kematian alami & $\mu$ & $\begin{array}{l}5,48 \times \\
10^{-5} / \text { hari }\end{array}$ & $\begin{array}{l}5,48 \times \\
10^{-5} / \text { hari }\end{array}$ & $\begin{array}{l}\text { (Tian, } \\
\text { 2019) }\end{array}$ & et & \\
\hline $\begin{array}{l}\text { Laju penurunan } \\
\text { efektivitas vaksin }\end{array}$ & $\sigma$ & $10 \%$ & $30 \%$ & $\begin{array}{l}\text { (Tian, } \\
\text { 2019) }\end{array}$ & et & al., \\
\hline Laju inkubasi & $\psi$ & $0,1 /$ hari & $0,3 /$ hari & Asumsi & & \\
\hline Laju penyembuhan & $\gamma$ & $0,004 /$ hari & $0,004 /$ hari & $\begin{array}{l}\text { (Tian, } \\
\text { 2019) }\end{array}$ & et & al., \\
\hline $\begin{array}{l}\text { Laju kematian karena } \\
\text { penyakit }\end{array}$ & $d$ & 0,015/hari & 0,015/hari & $\begin{array}{l}\text { (Tian, } \\
\text { 2019) }\end{array}$ & et & al., \\
\hline $\begin{array}{l}\text { Laju pencemaran } \\
\text { lingkungan oleh manusia } \\
\text { yang mengakibatkan } \\
\text { kenaikan populasi bakteri }\end{array}$ & $\xi$ & $20 \mathrm{sel} / \mathrm{ml} /$ hari & $100 \mathrm{sel} / \mathrm{ml} /$ hari & $\begin{array}{l}\text { (Tian, } \\
\text { 2019) }\end{array}$ & et & al., \\
\hline Laju kematian bakteri & $\delta$ & $0,33 /$ hari & $0,33 /$ hari & $\begin{array}{l}\text { (Tian, } \\
\text { 2019) }\end{array}$ & $e t$ & al., \\
\hline
\end{tabular}

\subsubsection{Dinamika Populasi}

Dinamika populasi yang akan diamati adalah kondisi ketika $\mathcal{R}_{0}<1$ (Kasus 1) dan $\mathcal{R}_{0}>$ 1 (Kasus 2). Kondisi atau jumlah individu yang diamati pada setiap populasi diawal waktu adalah $S(0)=500, V(0)=90, E(0)=0, I(0)=50, B(0)=3000$, dan $R(0)=0$.

Dengan menggunakan nilai parameter pada Tabel 1 untuk Kasus 1 diperoleh nilai $\mathcal{R}_{0}=$ 0,49 . Sesuai dengan Teorema 1 , kondisi tersebut akan stabil pada titik tetap tanpa penyakit $T_{0}(S, V, E, I, B, R)=(613,1212,0,0,0,0)$. Nilai $T_{0}$ menunjukkan bahwa seiring dengan berjalannya waktu, hanya akan terdapat populasi manusia rentan dan populasi manusia tervaksin pada sistem atau lingkungan. Adapun dinamika populasi untuk kondisi ini dilihat pada Gambar 1.

Selanjutnya apabila digunakan nilai parameter Tabel 1 pada Kasus 2 akan diperoleh nilai $\mathcal{R}_{0}=3,33$. Menurut Teorema 2 dan 3 kondisi ini akan mengakibatkan sistem (1) stabil pada titik tetap endemik $T^{*}(S, V, E, I, B, R)=(185,362,0.23,4,1113,268)$. Hal ini menunjukkan bahwa pada kondisi ini, penyakit akan tetap ada di lingkungan. Pengamatan lebih lanjut mengenai dinamika populasi untuk kondisi ini dapat dilihat pada Gambar 2. 

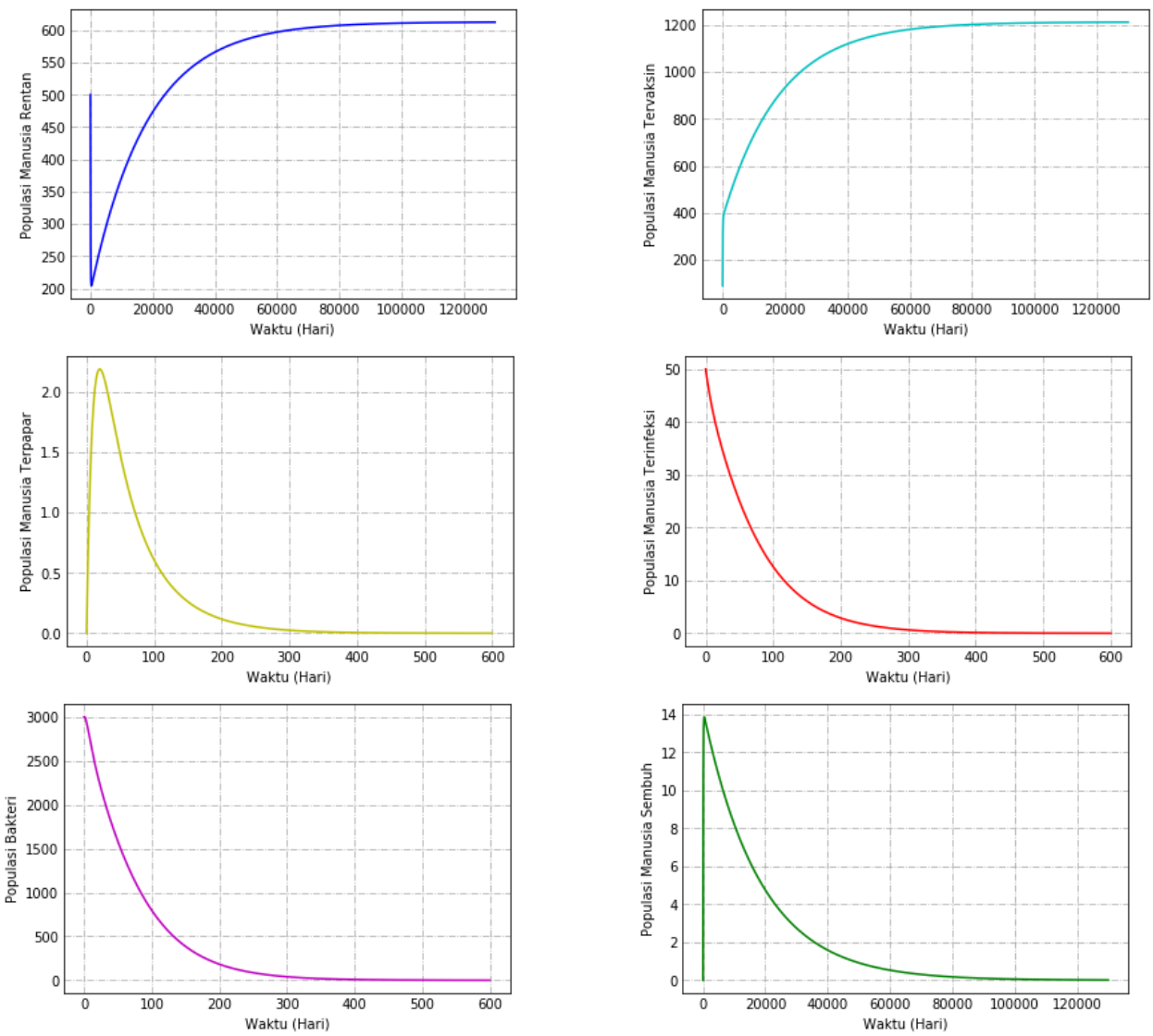

Gambar 2 : Dinamika Populasi Ketika $\mathcal{R}_{0}<1$

Pada Gambar 2 terlihat bahwa, seiring berjalannya waktu dinamika populasi manusia dan populasi bakteri mengalami kestabilan di sekitar titik tetap tanpa penyakit $T_{0}$. Jumlah individu rentan mengalami penurunan dari nilai awal hingga mendekati nilai 200 , kemudian jumlahnya bertambah hingga akhirnya stabil di sekitar $S=613$. Sedangkan jumlah individu tervaksin sejak awal terus mengalami peningkatan hingga akhirnya stabil di sekitar $V=1212$. Individu terpapar mengalami kenaikan dari nilai awal, kemudian menurun dan stabil di sekitar $E=0$. Hal serupa juga terjadi pada jumlah individu sembuh yang mengalami kenaikan dari nilai awal dan kemudian menurun serta stabil pada titik $R=0$. Adapun jumlah individu terinfeksi dan bakteri masing-masing mengalami penurunan sejak awal hingga akhirnya stabil di sekitar titik $I=0$ dan $B=0$. 

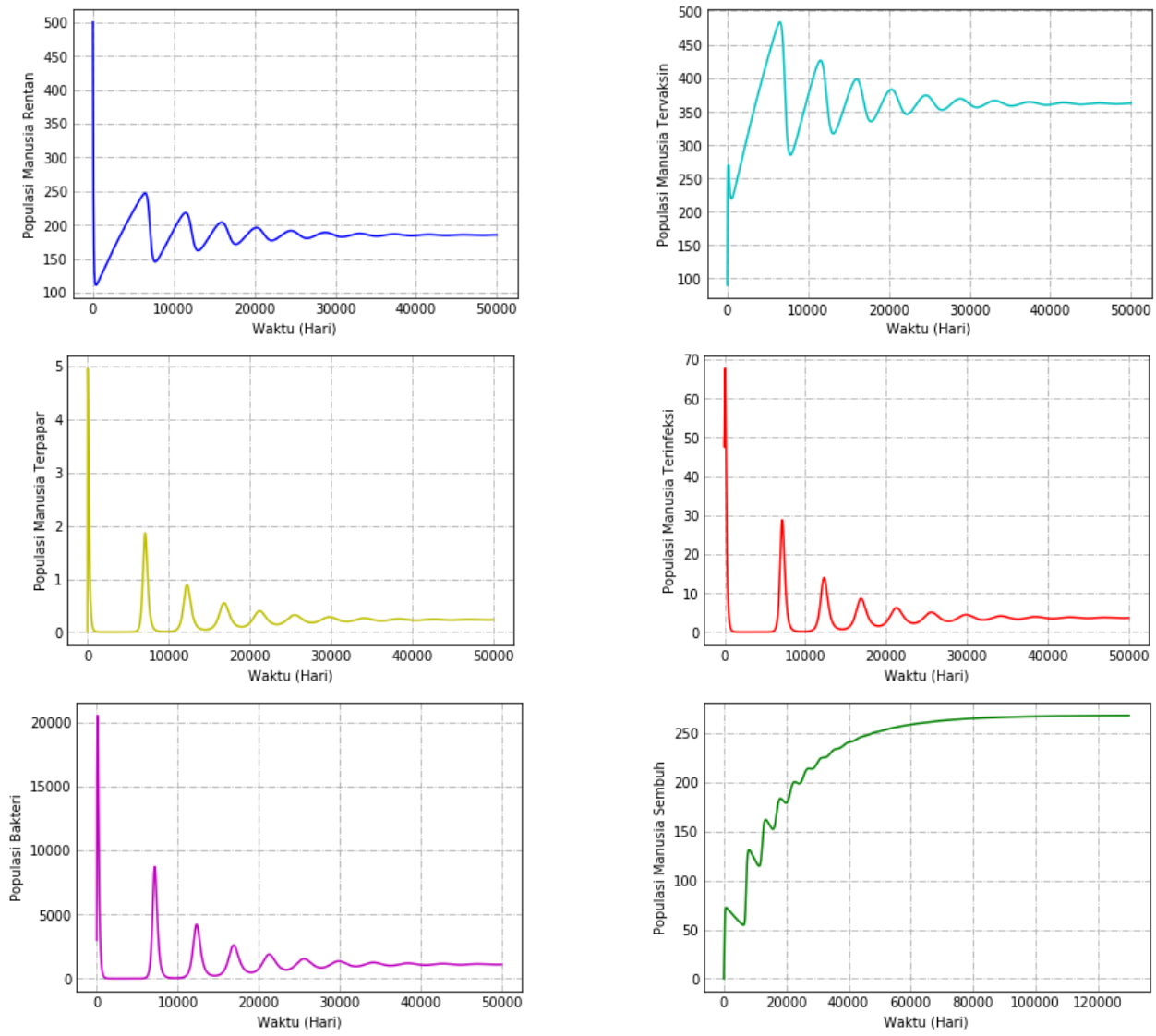

Gambar 3 : Dinamika Populasi Ketika $\mathcal{R}_{0}>1$.

Gambar 3 menunjukkan bahwa dinamika populasi manusia dan bakteri masing-masing mengalami fluktuasi diawal waktu sebelum akhirnya stabil di sekitar titik tetap tetap endemik $T^{*}$. Jumlah individu rentan dan terinfeksi masing-masing mengalami penurunan dari nilai awal hingga akhirnya mengalami fluktuasi dan mencapai kondisi stabil disekitar titik $S=185$ dan $I=$ 4. Hal berbeda ditunjukkan pada jumlah individu tervaksin dan sembuh, masing-masing mengalami kenaikan dari nilai awal kemudian berfluktuasi dan mengalami kestabilan di sekitar titik $V=362$ dan $R=268$. Adapun jumlah individu terpapar sejak awal waktu mengalami kenaikan, namun seiring berjalannya waktu jumlahnya kian menurun dan berfluktuasi hingga akhirnya stabil disekitar titik $E=0,23$. Sedangkan jumlah bakteri mengalami penurunan dari nilai awal kemudian berfluktuasi dan stabil di sekitar titik $B=1113$.

\subsubsection{Indeks Sensitivitas $\mathcal{R}_{\mathbf{0}}$}

Dinamika populasi juga dapat diamati berdasarkan perubahan nilai $\mathcal{R}_{0}$. Dalam hal ini bilangan reproduksi dasar menjadi tolak ukur seberapa besar tingkat infeksi akan terjadi di lingkungan. Salah satu cara yang digunakan adalah melihat indeks sensitivitas dari $\mathcal{R}_{0}$ menggunakan formula Chitnis (Chitnis, Hyman dan Cushing, 2008). Indeks sensitivitas juga 
dapat menunjukkan parameter apa saja yang paling sensitif atas perubahan nilai $\mathcal{R}_{0}$, agar dapat dilalukan upaya pencegahan mewabahnya suatu penyakit. Adapun nilai $\mathcal{R}_{0}$ yang akan dihitung tingkat sensitivitasnya adalah kondisi $\mathcal{R}_{0}>1$ serta menggunakan nilai-nilai parameter Kasus 2 pada Tabel 1. Pemilihan nilai $\mathcal{R}_{0}$ tersebut dikarenakan kondisi tersebut memungkinkan terjadinya wabah penyakit di lingkungan. Berdasarkan persamaan (2) diperoleh nilai indeksi sesitivitas untuk $\mathcal{R}_{0}$ yang ditunjukkan pada Tabel 2.

Tabel 2 : Indeks sensitivitas pada kondisi $\mathcal{R}_{0}>1$.

\begin{tabular}{c|c|c|c}
\hline Parameter $(p)$ & Indeks Sensitivitas $\left(\Upsilon_{\mathcal{R}_{0}}^{p}\right)$ & Parameter $(p)$ & Indeks Sensitivitas $\left(\Upsilon_{\mathcal{R}_{0}}^{p}\right)$ \\
$A$ & 1 & $\sigma$ & 0,3724 \\
$\phi$ & $-0,2918$ & $\psi$ & 0,000183 \\
$\beta$ & 1 & $\gamma$ & $-0,2099$ \\
$K$ & -1 & $d$ & $-0,7872$ \\
$\eta$ & 0,2886 & $\xi$ & 1 \\
$\mu$ & $-0,9999$ & $\delta$ & -1 \\
\hline
\end{tabular}

Pada Tabel 2 terlihat nilai indeks sensitivitas $\mathcal{R}_{0}$ ada yang bernilai positif dan bernilai negatif. Nilai positif menunjukkan perubahan nilai parameter berbanding lurus dengan perubahan nilai $\mathcal{R}_{0}$. Sebaliknya nilai negatif menunjukkan perubahan nilai parameter berbanding terbalik dengan perubahan nilai $\mathcal{R}_{0}$. Adapun parameter paling sensitif terhadap perubahan nilai $\mathcal{R}_{0}$ adalah laju kelahiran, laju transmisi bakteri dari lingkungan ke manusia, konsentrasi jenuh bakteri dalam air, laju pencemaran lingkungan oleh manusia yang mengakibatkan kenaikan populasi bakteri, dan laju kematian bakteri. Selain itu, terlihat bahwa parameter laju inkubasi memiliki nilai indeks sensitivitas paling rendah.

Nilai indeks sensitivitas pada parameter $\phi$ adalah $-0,2918$, artinya peningkatan nilai parameter laju vaksinasi sebesar satu satuan akan mengakibatkan berkurangnya nilai $\mathcal{R}_{0}$ sebesar 0,2918. Begitu juga dengan penurunan nilai parameter laju vaksinasi sebesar satu satuan akan mengakibatkan berkurangnya nilai $\mathcal{R}_{0}$ sebesar 0,2918 . Hal ini berarti pemberian vaksin sudah sangat tepat untuk menekan penyebaran penyakit. Pengaruh parameter laju vaksinasi juga dapat dilihat pada Gambar 4.
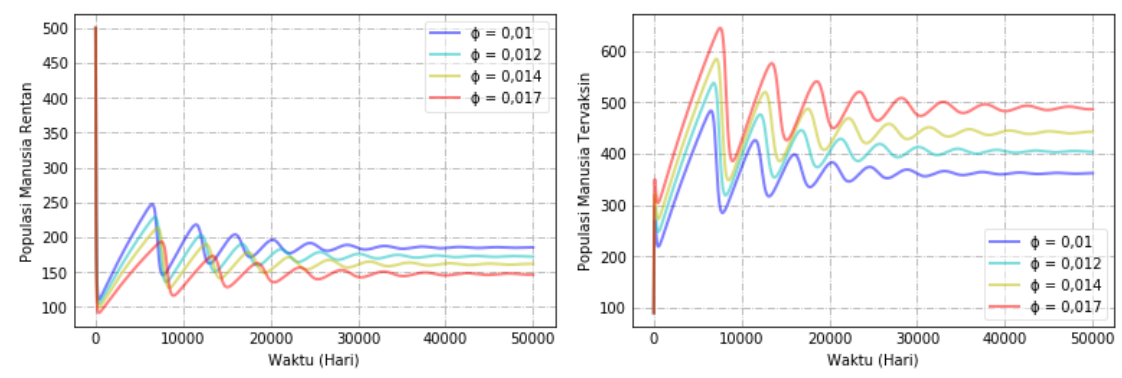

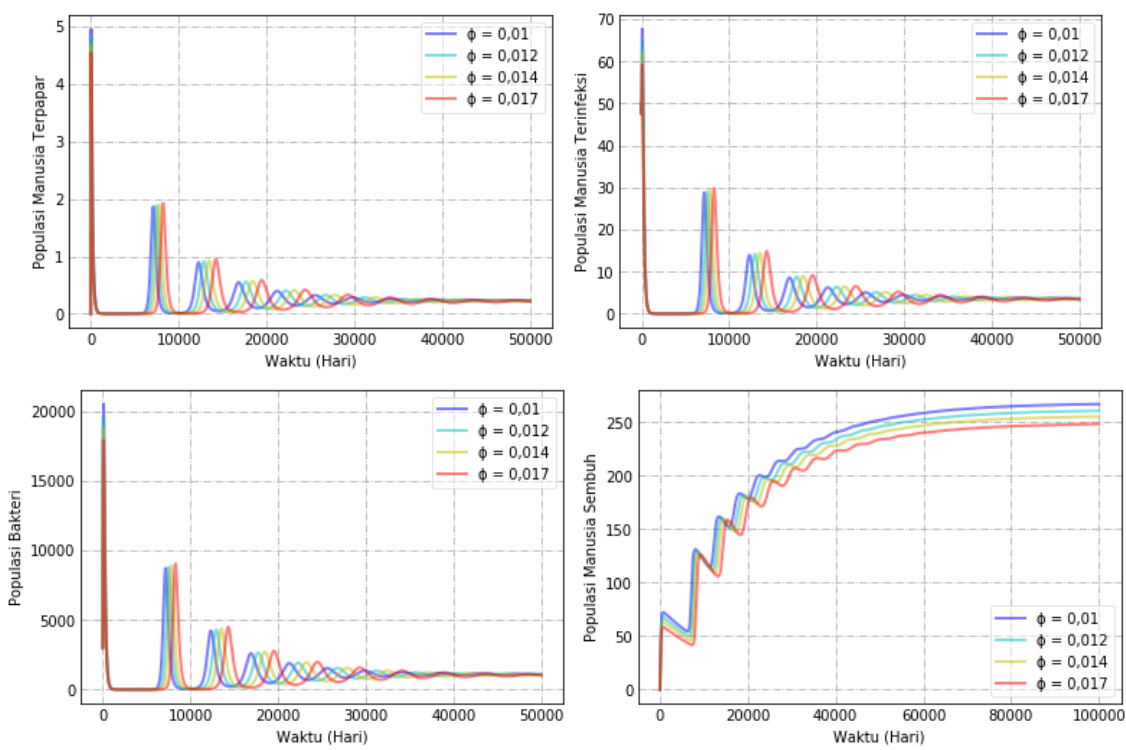

Gambar 4 : Pengaruh Laju Vaksinasi Terhadap Dinamika Populasi dengan $\mathcal{R}_{0}>1$.

Berdasarkan Gambar 4 terlihat bahwa peningkatan pemberian vaksin dapat mengurangi jumlah individu rentan dan meningkatkan jumlah individu tervaksin. Selain itu, vaksin juga memperlambat peningkatan jumlah individu pada populasi terpapar, individu pada populasi terinfeksi, dan populasi bakteri. Dengan demikian peningkatan pemberian vaksin merupakan cara yang dapat dilakukan untuk mengurangi tingkat penyebaran penyakit.

Untuk parameter $\eta$ pada Tabel 2 memiliki nilai indeks sensitivitas 0,2886 yang menunjukkan bahwa parameter laju penyusutan vaksin berbanding lurus dengan bilangan reproduksi dasar. Peningkatan parameter laju penyusutan vaksin sebesar satu satuan mengakibatkan bertambahnya nilai $\mathcal{R}_{0}$ sebesar 0,2886 . Sebaliknya penurunan parameter laju penyusutan vaksin sebesar satu satuan mengakibatkan berkurangnya nilai $\mathcal{R}_{0}$ sebesar 0,2886. Hal ini dapat menjadi dasar dan pertimbangan dalam pembuatan vaksin perlu dihasilkan vaksin yang dapat bertahan lama pada tubuh manusia. Gambar 5 memberikan ilustrasi untuk melihat lebih detail pengaruh parameter laju penyusutan vaksin terhadap dinamika populasi.
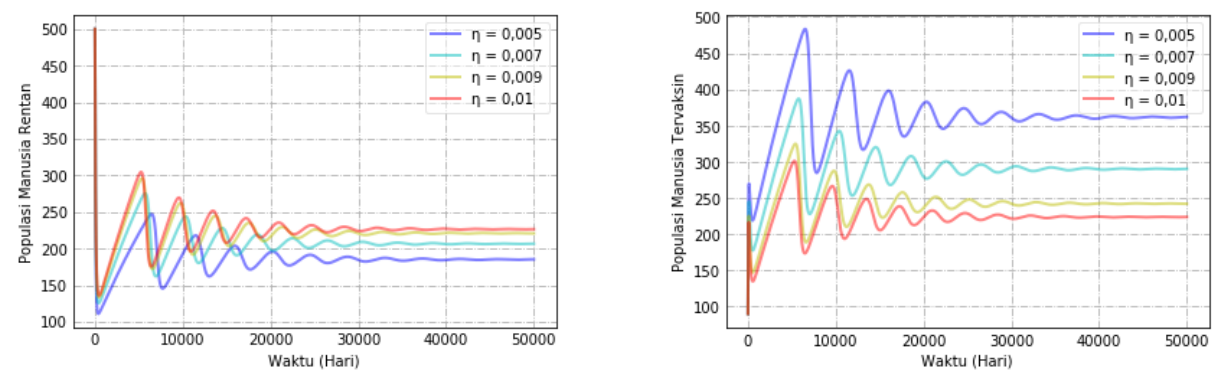

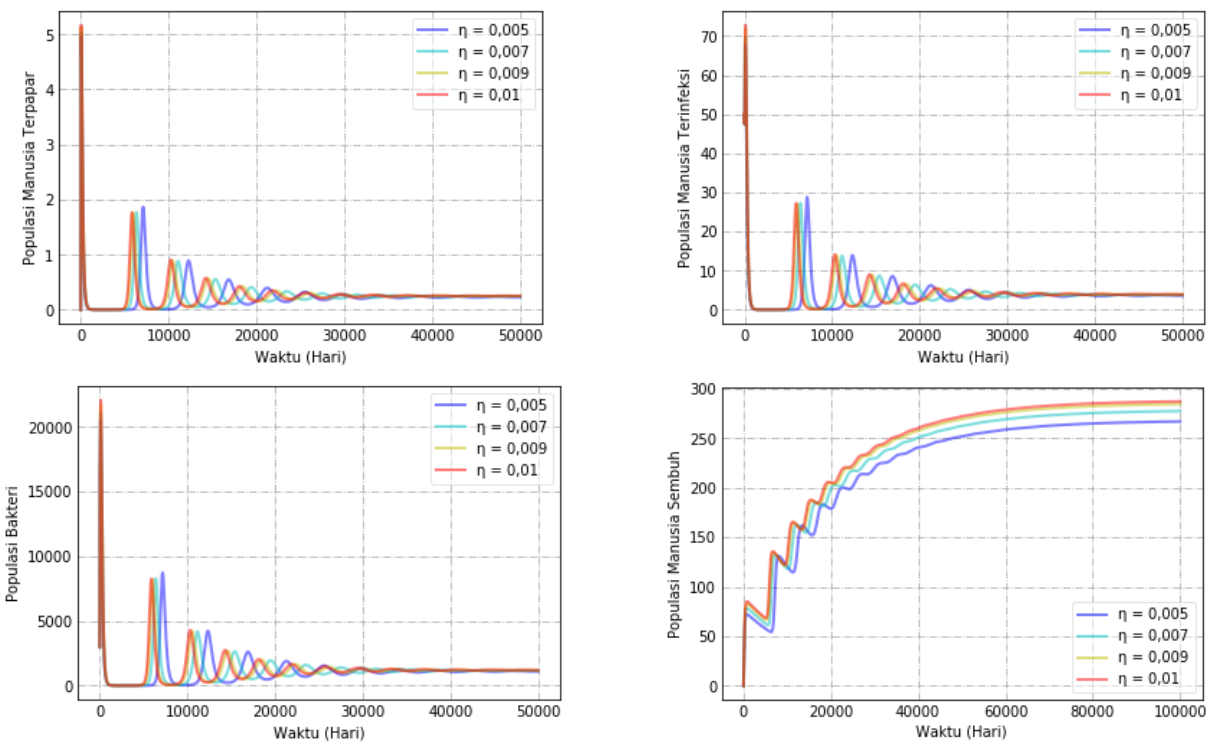

Gambar 5 : Pengaruh Laju Penyusutan Vaksin Terhadap Dinamika Populasi dengan $\mathcal{R}_{0}>1$.

Pada Gambar 5 terlihat bahwa peningkatan nilai parameter laju penyusutan vaksin mengakibatkan bertambahnya jumlah individu pada populasi manusia rentan dan menurunnya jumlah individu pada populasi manusia tervaksin. Hal ini menunjukkan bahwa penyusutan vaksin akan mengakibatkan semakin bertambahnya potensi terjadinya penularan penyakit. Selain itu, penyusutan vaksin juga dapat mempercepat pertambahan jumlah individu pada populasi manusia terpapar, populasi manusia terinfeksi, dan populasi bakteri.

Adapun parameter $\psi$ pada Tabel 2 memiliki nilai indeks sensitivitas 0,000183 . Walaupun nilai tersebut berbanding lurus dengan peningkatan bilangan reproduksi dasar, namun efek yang diberikan terbilang kecil. Peningkatan laju parameter laju inkubasi sebsar satu satuan mengakibatkan bertambahnya nilai $\mathcal{R}_{0}$ sebesar 0,000183. Sebaliknya penurunan laju parameter inkubasi sebesar satu satuan mengakibatkan berkurangnya nilai $\mathcal{R}_{0}$ sebesar 0,000183 . Adapun pengaruh laju inkubasi terhadap populasi manusia terpapar dan terinfeksi dapat dilihat pada Gambar 6.
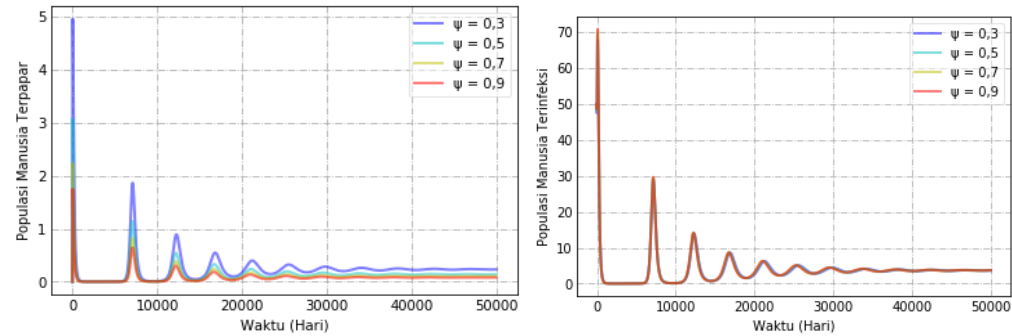

Gambar 6 : Pengaruh Laju Inkubasi Terhadap Dinamika Populasi Manusia Terinfeksi dan Terpapar dengan $\mathcal{R}_{0}>1$. 
Berdasarkan Gambar 6 terlihat peningkatan laju inkubasi akan mengakibatkan menurunnya jumlah individu pada populasi manusia terpapar. Hal ini disebabkan oleh semakin banyak individu yang bergerak atau berpindah dari populasi manusia terpapar masuk ke populasi manusia terinfeksi.

\section{KESIMPULAN}

Modifikasi model pada penelitian ini dilakukan dengan menambahkan populasi manusia terpapar pada model acuan sehingga menghasilkan model penyebaran penyakit kolera tipe SVEIR-B. Analisis kestabilan model menunjukkan terdapat dua titik tetap, yaitu titik tetap tanpa penyakit $T_{0}$ dan titik tetap endemik $T^{*}$. Jika $\mathcal{R}_{0}<1$, maka titik tetap tanpa penyakit $T_{0}$ bersifat stabil asimtotik lokal sedangkan jika $\mathcal{R}_{0}>1$, maka titit tetap endemik $T^{*}$ bersifat stabil asimtotik lokal. Hasil simulasi numerik menunjukkan peningkatan laju pemberian vaksin dapat memperlambat terjadinya infeksi dan menurunkan nilai $\mathcal{R}_{0}$, sedangkan peningkatan laju penyusutan vaksin dan laju inkubasi masing masing dapat mepercepat terjadinya infeksi dan meningkatkan nilai $\mathcal{R}_{0}$.

\section{DAFTAR PUSTAKA}

[1] Allen, L. J. S. dan Lahodny Jr, G. E., "Extinction Thresholds In Deterministic and Stochastic Epidemic Models," Journal of Biological Dynamics, 6(2), 2012, hal. 590-611. Tersedia pada: http://dx.doi.org/10.1080/17513758.2012.665502.

[2] Castillo-chavez, C. dan Song, B., "Dynamical Models Of Tuberculosis and Their Applications," Mathematical Bioscienes and Engineering, 1(2), 2004, hal. 361-404.

[3] Chitnis, N., Hyman, J. M. dan Cushing, J. M., "Determining Important Parameters in the Spread of Malaria Through the Sensitivity Analysis of a Mathematical Model," 2008, Bulletin of Mathematical Biology, 70, hal. 1272-1296. doi: 10.1007/s11538-008-9299-0.

[4] Codeco, C. T., "Endemic and Epidemic Dynamics of Cholera: The Role of The Aquatic Reservoir," 2001, BMC Infectious Diseases, 1(1).

[5] Deen, J., Mengel, M. A. dan Clemens, J. D., "Epidemiology of Cholera," 2019, Vaccine, 38, hal. A31-A40.

[6] Driessche, P. Van Den dan Watmough, J., "Reproduction Numbers and Sub-threshold Endemic Equilibria for Compartmental Models of Disease Transmission,", 2002, Mathematical Biosciences, 180, hal. 29-48.

[7] Pezzoli, L., "Global Oral Cholera Vaccine Use, 2013-2018", 2019, Vaccine, 38, hal. A132A140. Tersedia pada: https://doi.org/10.1016/j.vaccine.2019.08.086. 
[8] Puspandari, N., Sariadji, K. dan Wati, M., "Identifikasi Penyebab Kejadian Luar Biasa Kolera di Papua Terkait Kontak Jenazah dan Sanitasi”, 2010, Widyariset, 13(2), hal. 69-74.

[9] Shaikh, H. et al., "Current and Future Cholera Vaccines,", 2019, Vaccine, 38, hal. A118-A126. Tersedia pada: https://doi.org/10.1016/j.vaccine.2019.12.011.

[10] Side, S., Sukarna dan Asfarina, G. T., "Analisis Kestabilan Penyebaran Penyakit Kolera Menggunakan Model SEIRS dengan Vaksinasi dan Faktor Treatment,", 2018, Journal of Mathematics, Computations, and Statistics, 1(2), hal. 155-168.

[11] Tian, X., Xu, R. dan Lin, J., "Mathematical Analysis of A Cholera Infection Model With Vaccination Strategy,", 2019, Applied Mathematics and Computation, 361, hal. 517535. Tersedia pada: https://doi.org/10.1016/j.amc.2019.05.055.

[12] Vannice, K. S. et al., "Clinical Development and Regulatory Points for Consideration for Second-Generation Live Attenuated Dengue Vaccines", 2018, Vaccine, 36, hal. 34113417. Tersedia pada: https://doi.org/10.1016/j.vaccine.2018.02.062.

[13] Wang, J. dan Modnak, C., "Modeling Cholera Dynamics With Controls", 2011 Canadian Applied Mathematics Quarterly, 19(3), hal. 255-273.

[14] World Health Organization, "Cholera Vaccine: WHO Position Paper, August 2017 Recommendations", 2017, Vaccine, hal. 1-3. 